Analytic Framework for Evaluation of State Energy Efficiency and Renewable Energy Policies with Reference to Stakeholder Drivers

Elizabeth Brown and Gail Mosey
Technical Report NREL/TP-670-43539 July 2008 


\section{Analytic Framework for Evaluation of State Energy Efficiency and Renewable Energy Policies with Reference to Stakeholder Drivers}

Elizabeth Brown and Gail Mosey

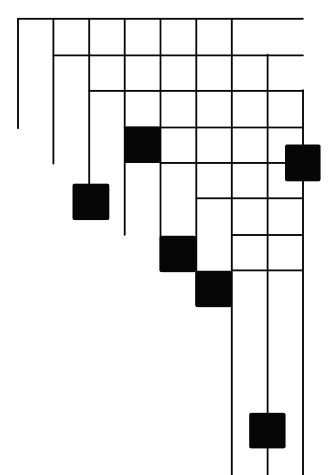

Prepared under Task No. IGST.8300 


\section{NOTICE}

This report was prepared as an account of work sponsored by an agency of the United States government. Neither the United States government nor any agency thereof, nor any of their employees, makes any warranty, express or implied, or assumes any legal liability or responsibility for the accuracy, completeness, or usefulness of any information, apparatus, product, or process disclosed, or represents that its use would not infringe privately owned rights. Reference herein to any specific commercial product, process, or service by trade name, trademark, manufacturer, or otherwise does not necessarily constitute or imply its endorsement, recommendation, or favoring by the United States government or any agency thereof. The views and opinions of authors expressed herein do not necessarily state or reflect those of the United States government or any agency thereof.

Available electronically at http://www.osti.gov/bridge

Available for a processing fee to U.S. Department of Energy and its contractors, in paper, from:

U.S. Department of Energy

Office of Scientific and Technical Information

P.O. Box 62

Oak Ridge, TN 37831-0062

phone: 865.576 .8401

fax: 865.576 .5728

email: mailto:reports@adonis.osti.gov

Available for sale to the public, in paper, from:

U.S. Department of Commerce

National Technical Information Service

5285 Port Royal Road

Springfield, VA 22161

phone: 800.553 .6847

fax: 703.605.6900

email: orders@ntis.fedworld.gov

online ordering: http://www.ntis.gov/ordering.htm 


\section{Purpose}

In 2007, the Department of Energy (DOE) and the National Renewable Energy Laboratory (NREL) began work with states to initiate the development of quantitative metrics to compare the impacts of different policy options for meeting the objectives of policymakers. The project is called the State Clean Energy Policy Analysis (SCEPA) Project. It is of critical importance to the project that the metrics are the product of a stakeholder process, so as to be most useful to states in their process of choosing appropriate energy efficiency (EE) and renewable energy (RE) policies. This summary paper describes the stakeholder input process through the spring/summer of 2007 and the resulting framework for quantification of policy impacts relative to stakeholder drivers. It is intended to provide context and background on the strategy for interested parties throughout the yearlong process of developing and evaluating policy options in relation to state policy drivers.

\section{Summary}

Quantification of benefits from the implementation of state-level EE and RE policies is a complex process, as stakeholders have a variety of different drivers, specific geographic resources, and needs resulting in a large number of "in-policy" variables, such as solar set-asides in renewable portfolio standards (RPS). A state stakeholder process was completed in the spring/summer of 2007 to identify the primary drivers for EE and RE policy development at the state level, and the most likely policy choices to meet those drivers. The general drivers identified as most critical are: economic development, environmental, and energy security. The likely policy choices for use in meeting EE and RE drivers primarily fall into categories of mandated demand reductions or supply developments (e.g., RPS and Energy Efficiency Resource Standards grants, rebates and loans, or code and permitting changes). A full list of the policies that stakeholders suggested is presented in Table 1.

This report presents the framework that was developed to analyze policies based on how well they meet the stakeholder drivers. The framework is a two-step process that initially quantifies the impact of the policies using metrics directly measured against each driver. The second stage of the process looks more closely at the "in-policy" specifics of different policies as applied (in existing policies) and quantifies, whenever possible, how well those individual variants meet the drivers. The framework also contains a qualitative discussion for how well each policy will apply to states with other resources and needs.

In late 2007, and throughout 2008, policies will be evaluated using the framework according to the stakeholder interest in each of the policies (see Table 1 for a list of policies).

\section{Stakeholder Process}

State policymakers and implementers are faced with a wide variety of energy policy choices and little quantitative evidence of success of the policies, especially as they are applied to the states' specific economic, baseline energy, governance, and resource situations. In the spring/summer of 2007, a stakeholder process was conducted to develop an analytic framework for policy 
evaluation to inform decision making. This paper summarizes the framework and the process used to develop it.

The public state stakeholder process, which was used to develop the framework, facilitates an open dialogue between the project implementers and the state stakeholders. This open dialogue was intended to promote the most useful outcomes of the project and bring together the wealth of dispersed knowledge on policy impacts. The framework is intended to house a wide variety of work in an accessible way to policymakers, so coordination of the status of the evaluation work is important to success.

Over the course of the spring, summer, and fall, a series of conference calls were held to describe the concept and solicit input on ideas for project development. Attendees on these calls included representatives from state associations (e.g., National Conference of State Legislatures, National Association of State Energy Officials, National Association of Regulatory Utility Commissioners), federal agencies (e.g., Department of Energy, Environmental Protection Agency), and states themselves. Between calls, the strategy and framework were revised and updated, and further input from interested parties was solicited for interim feedback. The final framework is the result of the iterative development among stakeholders of what policymakers' expectations are for energy policies, what kinds of policy options are available to states, and what measurements can be made to meaningfully and quantitatively measure the impacts of implemented policies and qualitatively describe the ramifications of those impacts.

\section{Analytic Framework}

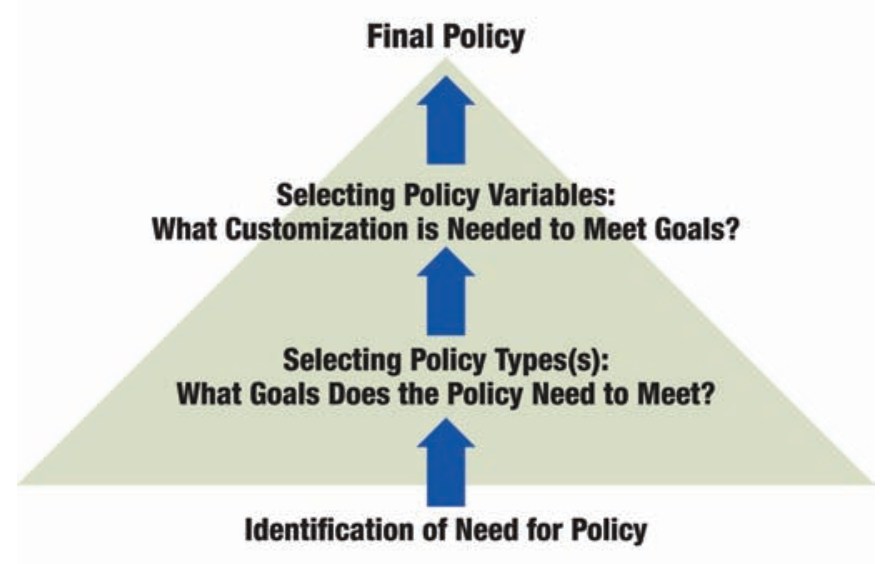

Figure 1. Conceptual policy decision-making process
The purpose of the project is to develop an evaluative framework of policy options to assist state policymakers in EE and RE policy choice and design. The focus is not on whether the in-place policies in states are successful—although this is taken into consideration when developing the metricsbut rather on the impact that those policies may have in other states and jurisdictions. For that reason, the framework for evaluation is designed based on

a simple policy choice model (Figure 1). The first phase of the policy choice model is to determine how a policy type meets the state driver. The second phase is the selection of in-policy variables that apply directly to the resources, demographics, and specific drivers within the state.

The data used to fill in the framework is based on evaluation of current polices and what is known about their actual function in the marketplace. The focus of previous policies is from the United States, but international examples are used where U.S. application information is not 
available. One of the challenges in using current policies is that many EE- and RE-focused policies are relatively new and impacts have not been established. In other words, the state "laboratories" of many new EE and RE policies are just starting to conduct their "experiments" and do not yet have conclusive findings. Where policies have not been in place long enough in one state to evaluate and extrapolate what the impacts will be in other states, estimates based on projected impacts are used. These distinctions will be noted throughout the project for each of the specific policies.

\section{Step 1: Overarching Policy Drivers and Evaluating Individual Policy Impact on Drivers}

The selection of the primary policy drivers was developed in consultation with state actors. Figure 2 illustrates the categorization scheme for policies into the primary drivers and the metrics associated with each driver. The resulting drivers from that discussion are general enough to cover a wide variety of state needs, but specific enough to be categories through which a decision maker can choose a policy. These are:

- Economic Development - State policymakers and implementers have an interest in promoting new industries and job creation within the state and making a positive impact on state revenues.

- Environmental - State policymakers and implementers have an interest in protecting and improving local air quality by decreasing the release of air pollutants, including carbon and carbon equivalent greenhouse gas emissions (GHGs).

- Energy Security/Fuel Diversity - Reducing dependence on foreign fuels and increasing self-sufficiency are priority goals for many states, both as a way of increasing the local economy and stabilizing energy prices.
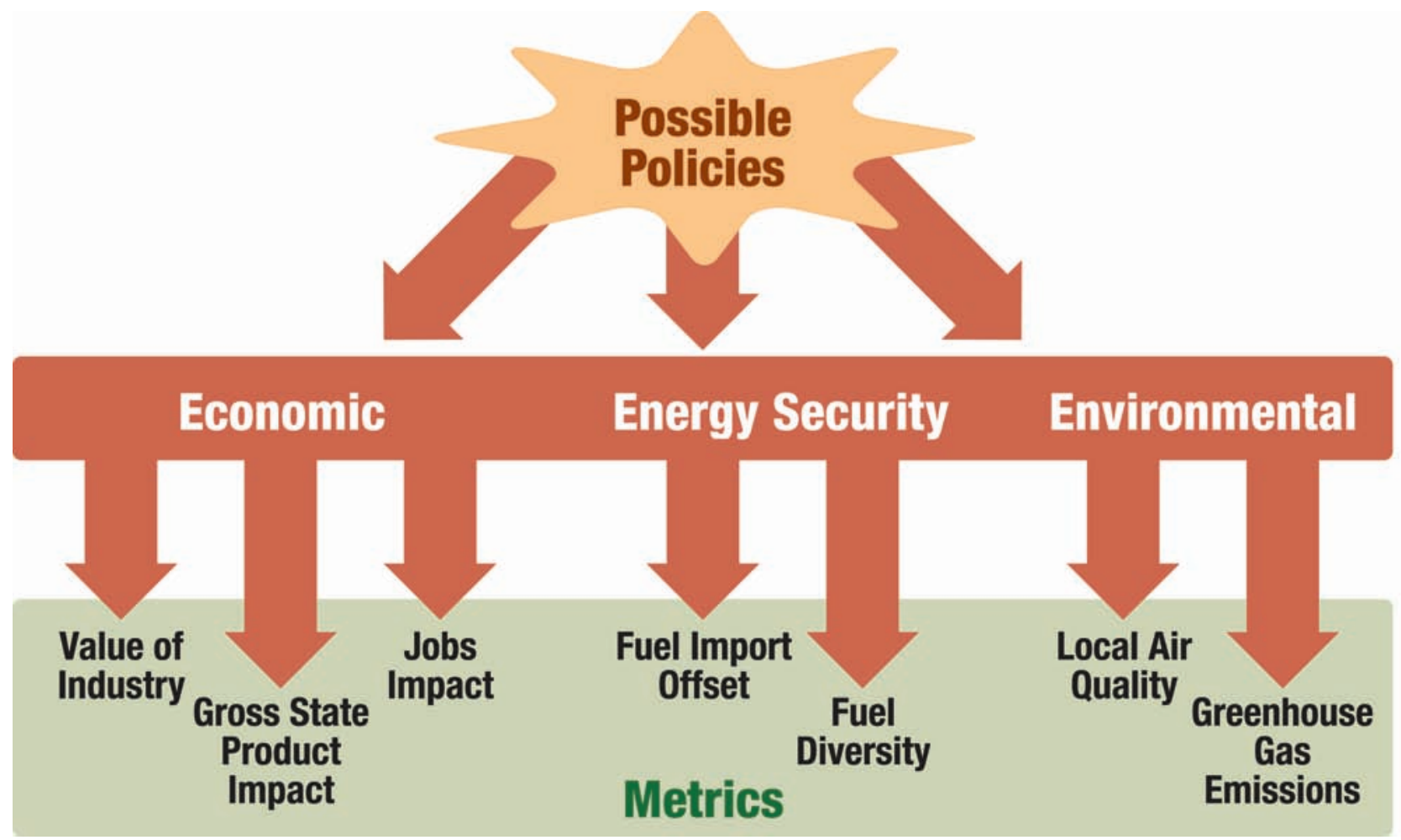

Figure 2. Framework for categorizing policies by impact on drivers 
From each of the primary drivers, metrics are developed for the purpose of comparing policies on impact (Figure 2, bottom). These metrics are general, but provide guidelines for policy analysis that apply to a broad range of EE and RE policies in both the electric and fuels sectors. The metrics are intended to pull from the successes of policy types in states and estimate their applicability within other states. Although the initial metrics and metric categories are presented below, it is expected that these metrics will evolve throughout the project.

\section{Metrics}

- Economic Development in the state - Economic development metrics are intertwined and the separation into three individual metrics is intended to capture broad impacts of different policies.

$\circ$ Value of Industry - The value of the industry to the state is measured in the dollar value of the industry relative to overall industry in the state. This can be expressed as a percentage change to develop a range of possible changes resulting from policies given state resources.

○ Gross State Product Impact - Closely related to the value of the industry, this measure also includes ancillary impacts (e.g., facilitating technology industry development) of a growing industry as the result of the policy.

- Job Impact - This measurement reflects state policymaker interest in increasing job creation in the state. This measurement can also be presented as a percentage by job development type where data is available in order to inform policymakers in states with different workforce attributes.

- Energy Security

- Fuel Import Offset - Fuel import offset is primarily a measure for fuel-related policies. State stakeholders cited reducing imports as a top priority, and many fuel policies are designed around this goal. The direct measurements are reduced gallons imported to the state from both international locations and other states.

- Fuel Diversity - Most closely related to more typical measures of policy success, this measure is the amount of EE and RE installed/created as a result of the policy. The measurements include increased installed capacity as a result of the policy and increased gallons of alternative fuels or kilowatt hour $(\mathrm{kWh})$ of alternatively produced electricity. These measurements are measured relative to the overall energy mix.

- Environmental

- Local Air Quality Impacts - Air quality impact is measured in particulate emissions reductions of Clean Air Act regulated pollutants resulting from the policy.

- Greenhouse Gas Emissions - The lack of long-term experience and direct measurements of carbon and carbon equivalent gas emissions reductions create the primary challenges to measuring these impacts. Unless otherwise available, these carbon impacts will be calculated indirectly from decreased carbon-based fuel and electricity use from utility portfolios with a high percentage of fossilbased fuels. 


\section{Step 2: In-Policy Variables and Applicability to Other States}

As expected, the quantification of policy impacts to assist states in policy decision making is complicated because it depends not only on the drivers for the policy, but also on attributes of the state such as resource availability (both financial and EE or RE resource availability), ability to use or transport the fuel or electricity to demand areas, and/or the extent to which constituents are willing to internalize the costs of environmental and energy security metrics. These "inpolicy" variables are specific to states as unique entities and can have a large impact on the success of the policy. Furthermore, they are hardest to quantify in terms of expected impacts in other states for this same reason of state uniqueness.

This methodology of approaching "in-policy" variables is designed from the perspective of the policymaker designing a new policy. That is, the framework focuses on the applicability of these "in-policy" variables as to which variables are the most applicable to other states, and what about the variables made the policy successful from the perspective of the primary drivers for the policy. For example, if a RPS with a solar set-aside in a particular state is successful, the applicability measure will focus on what in that state made the policy successful and what attributes a state should have if it is to expect the same success. In this case, the "in-policy" variable may likely be the amount of solar resource, or some aspect thereof.

These "in-policy" variable metrics will vary widely between policies and will be developed quantitatively where possible; otherwise, they will be assessed qualitatively. This process will largely be developed for each policy during research into the policy in order to understand the impact of the policy against each of the drivers. For that reason, no further detail will be discussed here, but thorough documentation will accompany each policy analysis.

\section{Prioritized Policies Under Consideration}

As different policies are evaluated, it is expected that the framework will provide opportunities for the analysis team to learn from experience, and the framework will evolve into a more robust scheme for application. To that end, the selection of policies and the timeline in which they will be evaluated is based on two primary factors:

1) Urgency for states - Popular policies, in particular, will be give priority to have the most unified and quantitative information in the near term.

2) Known information - The policies with the longest histories and the most experience are used to test the current framework and identify challenges for quantification and opportunities for further framework development.

Policy selection was based initially on listings of available policy types, such as those listed by the Database of State Incentives for Renewables and Efficiency (DSIRE), (http://www.dsireusa.org), and other resources. The list was augmented by policy experts and state stakeholder input. The order of the policies for completion was also developed with input from state stakeholders. Table 1 presents the list of policies considered. The current timeline can be found at the project Web site: http://www.nrel.gov/applying technologies/scepa.html. 
Table 1. Policy List

\begin{tabular}{|l|}
\hline Renewable Portfolio Standards \\
\hline Renewable Fuels Standards \\
\hline Energy Efficiency Resource Standards \\
\hline Decoupling/Lost Revenues/Incentives \\
\hline EE Tax Incentives: Personal \\
\hline EE Tax Incentives: Corporate \\
\hline EE Tax Incentives: Sales \\
\hline EE Tax Incentives: Property \\
\hline Tax Incentives: Corporate Electric \\
\hline Tax Incentives: Corporate Auto alt fuels \\
\hline Renewable Products Grants and rebates \\
\hline EE Rebates \\
\hline EE Grants \\
\hline EE Loans \\
\hline EE Pay As You Save \\
\hline EE QAP Allocations for Efficiency \\
\hline EE Bonds \\
\hline Administration of EE Programs \\
\hline Green Building Incentives \\
\hline RE Tax Incentives: Personal DG/Net Metering, Property Tax \\
Exemptions, Easements, Sales Tax Exemptions \\
\hline RE/Alt Fuels Tax Incentives: Personal Auto \\
\hline Demand Response Programs \\
\hline Feed in tariffs \\
\hline Nontraditional Rate Structures: TOU (EE and RE) \\
\hline Nontraditional Rate Structures: Inverted Block (EE and RE) \\
\hline EE Public Benefit Funds \\
\hline PBF Renewable Related Policies \\
\hline Consumer Information/Education \\
\hline Building Codes \\
\hline Appliance Standards \\
\hline Performance Contracting \\
\hline Standards for Public Buildings \\
\hline Renewable Project Contracting and Financing \\
\hline Transmission Policies \\
\hline Industry Recruitment incentives \\
\hline Loans \\
\hline Standardized Permitting for Renewables \\
\hline
\end{tabular}

\section{Project Next Steps}

Based on the framework developed through the stakeholder process, evaluation of the policies began in November 2007. Information gathered on policies and analysis completed, as well as challenges and opportunities surrounding the metrics for informing policy choice, will be updated on the project Web site at http://www.nrel.gov/applying technologies/scepa.html. 


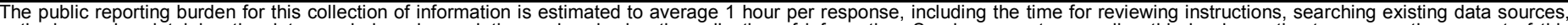

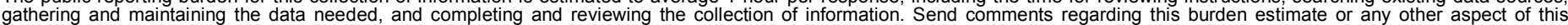

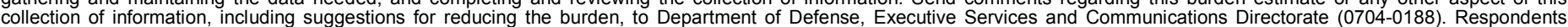

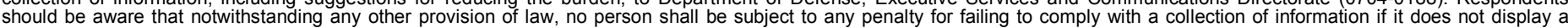

should be aware that notwithstanding

PLEASE DO NOT RETURN YOUR FORM TO THE ABOVE ORGANIZATION.

\begin{tabular}{l|l}
\hline $\begin{array}{l}\text { REPORT DATE (DD-MM-YYYY) } \\
\text { July } 2008\end{array}$ & $\begin{array}{r}\text { 2. } \\
\text { REPORT TYPE } \\
\text { Technical Report }\end{array}$ \\
\hline 4. $\begin{array}{l}\text { TITLE AND SUBTITLE } \\
\text { Analytic Framework for Evaluation of State Energy Efficiency and } \\
\text { Renewable Energy Policies with Reference to Stakeholder Drivers }\end{array}$
\end{tabular}

6. AUTHOR(S)

E. Brown and G. Mosey

3. DATES COVERED (From - To)

5a. CONTRACT NUMBER

DE-AC36-99-G010337

5b. GRANT NUMBER

5c. PROGRAM ELEMENT NUMBER

5d. PROJECT NUMBER

NREL/TP-670-43539

5e. TASK NUMBER

IGST.8300

5f. WORK UNIT NUMBER
7. PERFORMING ORGANIZATION NAME(S) AND ADDRESS(ES)

National Renewable Energy Laboratory

1617 Cole Blvd.

Golden, CO 80401-3393

9. SPONSORING/MONITORING AGENCY NAME(S) AND ADDRESS(ES)
8. PERFORMING ORGANIZATION REPORT NUMBER

NREL/TP-670-43539

10. SPONSOR/MONITOR'S ACRONYM(S) NREL

11. SPONSORING/MONITORING AGENCY REPORT NUMBER

12. DISTRIBUTION AVAILABILITY STATEMENT

National Technical Information Service

U.S. Department of Commerce

5285 Port Royal Road

Springfield, VA 22161

13. SUPPLEMENTARY NOTES

14. ABSTRACT (Maximum 200 Words)

Quantification of benefits from the implementation of state-level energy efficiency (EE) and renewable energy (RE) policies is a complex process, as stakeholders have a variety of different drivers, specific geographic resources, and needs resulting in a large number of "in-policy" variables, such as solar set-asides in renewable portfolio standards (RPS). A state stakeholder process was completed in the spring/summer of 2007 to identify the primary drivers for EE and RE policy development at the state level, and the most likely policy choices to meet those drivers. The general drivers identified as most critical are: economic development, environmental, and energy security. The likely policy choices for use in meeting EE and RE drivers primarily fall into categories of mandated demand reductions or supply developments. This report presents the framework that was developed to analyze policies based on how well they meet the stakeholder drivers. The framework is a two-step process that initially quantifies the impact of the policies using metrics directly measured against each driver. The second stage of the process looks more closely at the "in-policy" specifics of different policies as applied (in existing policies) and quantifies, whenever possible, how well those individual variants meet the drivers. The framework also contains a qualitative discussion for how well each policy will apply to states with other resources and needs.

15. SUBJECT TERMS

energy efficiency; renewable energy; policy; state policy; stakeholder drivers; economic development; environmental; energy security; fuel diversity

16. SECURITY CLASSIFICATION OF:

\begin{tabular}{l|l|l}
\hline $\begin{array}{l}\text { a. REPORT } \\
\text { Unclassified }\end{array}$ & $\begin{array}{c}\text { b. ABSTRACT } \\
\text { Unclassified }\end{array}$ & $\begin{array}{c}\text { c. THIS PAGE } \\
\text { Unclassified }\end{array}$ \\
\end{tabular}

\begin{tabular}{|c|c|}
\hline $\begin{array}{l}\text { 17. LIMITATION } \\
\text { OF ABSTRACT }\end{array}$ & $\begin{array}{l}\text { 18. } \\
\text { NUMBER } \\
\text { OF PAGES }\end{array}$ \\
\hline UL & \\
\hline
\end{tabular}

19a. NAME OF RESPONSIBLE PERSON

19b. TELEPHONE NUMBER (Include area code) 